\title{
Contemporary Educational Paradigm In The Context of Muslim Community Awareness of Yogyakarta
}

\author{
Dr. Usman, SS, M.Ag. \\ State Islamic University of Sunan Kalijaga, Indonesia
}

\begin{abstract}
New findings of this research were Jahiliyyah, Diniyyah, Ilmiyyah, and Hanifiyyah. Jahiliyyah awareness and its educational paradigm is based on the idea of human beings that behave doubles: they understand something, but at the same time they act deliberately stupid. Diniyyah awareness and its educational paradigm is based on the doctrine that man should cling to the teachings of Islam. Ilmiyyah awareness and its educational paradigm is based on a world view of life as it is. Humans have creativity, innovation, and progress, but their behaviors are mechanical and systemic. Hanifiyyah awareness and its educational paradigm is based on a world view of life that the humans are rational figures (progressive). Learning is a process of becoming (To Be).
\end{abstract}

Keywords: Educational Paradigm, Muslim Awareness, New Islamic Educational Theory, Simultaneous Relationship Between Muslim community awareness and Their Educational Paradigm.

\section{Introduction}

Discussion of educational philosophy covers aspects of education, which include at least basic education (ontology, epistemology, and axiology), human concept, the concept of theory and methods of learning, and the concept of curriculum. These essential aspects can be found in people's lives, whether formal, informal, non-formal, and internal. In fact, aspects of education have their own uniqueness, which are caused by a type of its consciousness, which also form the educational paradigm, and their relationship. It is necessary to discuss the types of Yogyakarta Muslim community awareness and education paradigm, while comparing it to the stage of awareness and educational paradigms that have been discussed by several experts, such as Auguste Comte, C.A van Peursen, Paulo R.N. Freire, M. 'Abid al-Jabiry, and Kuntowijoyo. The research findings describe new kinds of awareness and educational paradigm typical of the Muslim community of Yogyakarta and their contribution to the development.

\section{Review of Related Literature}

The relationship between the stage of awareness and educational paradigms have discussed by several experts. The first is Auguste Comte. He explained that the human mind is divided into three kinds of consciousness: (1) theological consciousness reflects the directional nature of the human mind in an attempt to make contact with every issue of life or the Absolute First Cause; (2) metaphysics describes the human mind leading to designation of abstract or substantial; (3) positive stage describes the stage of human consciousness which establishes that truth is real, measurable, observable, and verifiable. The first and second phases are regarded as a speculative nature that mind is patterned, so the truth is questionable. Truth can be achieved through natural positive thoughts [1].

The consequences of a positive phase of the awareness in the educational paradigm is the loss of connection with the structures and systems that exist in society, such as social order, politics, culture, and values . This is caused by foundation that objectivity is how to understand reality itself off from its relationship with other things. Therefore when such issues emerge in education, the liberals will see human qualities. The solutions of the problems are limited to revamping the educational facilities, methods of learning; emphazising on learning by doing, and tailoring the core curriculum to the needs of the community; here's where the term link and match gets the place [2].

The second expert is C.A van Peurse that describes three stages of human consciousness, namely mythical, ontological, and functional. First, in Comte the third stage is positive. This stage describes the shape of human consciousness to see that the two previous phases, i.e. captivity and final truth, as an individual consciousness. Every subject of life cannot be understood in isolation, but always in relation to each other. Second, the law of the three stages of Comte implies hierarchical structure from the first to the third [3]. Although the categorization of human consciousness and their explanations are different, van Peursen's paradigmatic notion looks positivistic. This is evident from the assertion,

"... That attitude will not like these functional systems that are completely round and speculative views that explain everything. ... In one school of modern philosophy as opposed to the philosophy of existentialism, the 
flow of positivism (especially logical positivism and analytic philosophy) functional properties was clearly visible. They rejected as an expression of metaphysical figment all that talk about the substance, the soul, God, if the words cannot be shown in the world that can be groped, in the world of science. ... " [4].

Questioning the meaning means something must integrate it in lived experience or practiced human. This view is in line with the pragmatic ideas of John Dewey, who argued that education is an effort to reorganize human experiences [5]. This means that the source of the problem lies in the quality of human. To solve this problem, management of culture or form of cultural strategy, from the mythical and theological toward functional must be done.

The third view is by Paulo R.N. Freire describes three stages of human consciousness: (1) semiintransitive stage is characterized by humans obsessed with socially-created myths. Their attitudes and behavior are unfounded independence, commanded by the community group whose viable mythic must be obeyed. They live in a downtrodden, inferior, insecure, and other psychological atmosphere [6]; (2) transitive-naïve stage, characterized by a higher form of consciousness is to see the man as the cause of the problems of life. For example, ethical, creative, dynamic, progressive, and other characters which appears because humans are lazy, spiritless, and does not have an entrepreneurial spirit [7]; (3) transitive-critical, i.e., human consciousness to see the source of the life caused by the structure and systems: social, political, economic, and cultural condition that makes man conscious and critically aware of their transformative action against the systems and structures that have shackled their lives [8].

The imbalanced relationship between educators with the learners is not based on the dialectical relationship, while in the transitive-critical stage the relationship is more human, communicative. That Andragogy approach [9], asserts that teacher is facilitator, because teachers and students are the subjects.

The fourth view is by Muhammad 'Abid Al-Jabiry. He classifies three stages of consciousness, i.e. bayani, 'irfani, and burhani. First, bayani is the mind based on two main principles of discontinuity (infishal) and contingency (tajwiz). The principle of contingency is based on rationality and logic games, while evidence of natural law of Allah is not involved in its implementation. Theologians use actual reality (martyr) to describe the reality that is not real (unseen) or qiyas al-gāib 'ala al-syāhed (analogical way of unseen to reality), it is called qiyas. Qiyas is not a valid method, because it analogizes something with something else based on their shared similarities, and based on the presumption [10]. In education, this is reflected in the imitative pattern of relationships between educators and educated. Transfer of knowledge takes place in one-directional manner where there is no dialogue, no criticism, and improvisation, but instruction. Educators are as the source of truth or the major premise in the syllogistic reasoning [11]. Second, 'irfan means knowledge and the highest kind of knowledge 'Arifin is acquired directly through "Kasyf"/inspiration. The acquisition of knowledge is not engineered by itself, but it is revealed. The role of 'Arifin as a subject is not independent, but "participatory". Humans should prepare themselves while waiting for God to unfold the sacred veil, so that the knowledge gained is very highly valid [12]. The effect of instructively-patterned awareness of the educational paradigm and educators is very dominant in the acquisition of knowledge and quality-controlled education. God's will determines the blessing and pleasure in the acquisition of knowledge. Therefore, it is understood that the transfer of knowledge flows in a linear, without innovation and without criticism. Then the process of knowledge acquisition and development is in the affective realm, instead of cognitive [13]. Third, burhani is a demonstrative reasoning system, which is based on the principle of causality between the elements. Burhani establishes that the truth proceeds from examining the real natural facts, then goes up to find the metaphysical nature to the nature of divinity. [14]. In burhani, rational thinking is the application of natural law and within the scope of necessity. Humans actually are in a natural state; affects and is affected by the realities of life, such as diseases (pain), but the next pandemic could be eradicated (conditioned, thus recovering from illness)). It indicates the space for people to do (create, improvise). The efforts here are to establish the character of rational critical thinking [15]. The paradigm of education shows that the ongoing relationship between educators with educated is creative, dialogue, critical, and human. It was described by al-Jabiry with a culture dependent (Islamic Arab culture) to another culture/hegemony (American culture) in the process of establishing its own culture [16].

The fifth view is by Kuntowijoyo describes the Indonesian Muslim community awareness: (1) mythical, (2i) ideological, (3) scientific. Mythical stage people feel as grassroots, where unity and cohesion is based on fanaticism by following blindly the order of the authority, for their power and knowledge [17]. Therefore, pattern of relationship is instructive, depending on the educators [18]. Ideological consciousness [19]. The country's independence burned the spirit to organize the life of politics, law, and others. During the transition, the spirit of independence was marred with the fanatical tribal separatists. Such fanaticism brought the same attitudes and behavior as in the mythical stage. There were efforts to shifts towards the use of models and leveled classroom, and sustainable enforcement of standard models curriculum. However, it did not create a paradigm shift. Western civilization brought about changes in awareness model of Indonesian Muslim to be 
scientific [20] as third stage. Traditional way of life was transformed and the progress of science and technology, social, political, and cultural plural patterned took place, where irrational approach was replaced with a rational approach (scientific). They adopted the Western scientific approach characterized by positivism and pragmatism as it is. This consciousness fosters a critical attitude to enact andragogis education system to replace paedagogis system, in which educator as instructor becomes educator as facilitator. Both educator and educated are the subject of education. However, their positivistic and pragmatic critical attitude formed the materialistic national character [21].

The writer notes that the social, political and cultural categories are always influenced by religious sentiment. They are connected to each other for the single purpose of worship. It means that their consciousness in political behavior and law is determined by the quality of their religious consciousness. From the data, the kinds of awareness is categorized into four types, namely jähiliyyah, diniyyah, 'ilmiyyah, and hanifilyyah. This categorization seems more specific, laden with religious value.

\section{Research Method}

This study uses a qualitative method, which describes the philosophy and implementation by research subjects that include ways of thinking and behaving. Philosophy of life is implemented in the form of education paradigm in the context of the Islamic awareness among the Muslim community in Yogyakarta. Thus, the object of study should be described as critical, but has pragmatic relevance to life today. The goal is to obtain an objective and systematic picture of facts, properties and characteristics as well as the relationship between the existing elements [22]. Furthermore, the material object is the form of education paradigm in the context of the Muslim community awareness in Yogyakarta, including the study of philosophy of education. To understand the intended meaning, the necessary procedures are described as follows: First, how to research. The data gathered for this study is the educational paradigm related to the type of Muslim community awareness of Yogyakarta as seen in political and legal behavior. For a political issue, the writer obtained data from the sympathizers of political parties such as PDIP, Golkar, the Democratic Party, PKS, PAN, PPP, and Gerindra, in the Regional House of Representatives. For the legal field, data was obtained from the public, law enforcement officials, the police, judiciary body and prosecutors. The data was obtained through documentation, analyzed and interpreted according to Patton's model [23], which includes field notes and researcher's comments, images, photographs, documents (eg. reports), biographies, and articles.

Second, process of research. To analyze it philosophically, the data was organized based on systems and patterns of research that is methods of analysis. This stage includes a reduction, classification, data display, interpretation and conclusion [24]. (1) In data reduction, the documents are summarized and sorted through to establish substantive subject matter. (2) Data is classified to determine the substantive problems associated with formal object/theory that serves as a tool of analysis of the underlying aspects of the type of public awareness; ontology, epistemology, and axiology, as well as aspects of the underlying paradigm of education; ontology, epistemology, axiology, human concept, theory and method of learning, and curriculum. (3) The data is displayed by mapping the substantive case and its aspect associated with it to extract meaning in context. (4) The interpretation and conclusions reveal aspects of underlying meaning of the type referred to public awareness and education aspect of the underlying paradigm. The interpretation method used in this research is Edmund Husserl's phenomenology. Awareness is intentionality which leads to something that was realized (the so-called object of intentionality; the form of political behavior and the law are summarized in the documentation). Then each activity realized (called activity of intentionality) is an activity to realize the effect of the so-called constitution, i.e. the process of understanding phenomenon by consciousness. In short, the data is constituted in such a manner that enables it to be incomprehensible [25]. For example, cases of police illegal transactions with bikers and money politics. The process of intentionality and constitution of the phenomenon revealed the ontology, epistemology and axiology of the legal and political behaviors. Furthermore, the phenomenon is read to find the essence/eidetis; it is a rational course of action which has no basis and aims. At this stage it could yield subjective result, because the subject may dominate the meaning/interpretation. To avoid subjectivity, the meaning should be done with pure consciousness. The ongoing constitutional process phenomenon/data and the meaning of the researcher as a subject investigator are callibrated to conclude a deliberate act of infringement. This is exactly what the researcher meant by intentionality and the constitutional process of the phenomenon by researchers creatively and appearance of the object itself (selbstverstandlichkeit).

Third, Comparison. This section describe, display, compare particular characteristics, and evaluate critically each of the experts' thought, and then draw conclusions [26]. The writer made a comparative analysis on the experts' ideas and concept, as well as the types of public awareness and education paradigm to find a fundamental divergence. The steps are describing each concept, displaying the data; mapping the substantive cases and relevant aspects, and finding traits, and finally making inferences. 


\section{Results}

1. Meaning of Consciousness and Paradigm

Consciousness, according to Edmund Husserl, is intentionality that leads to something that is realized (intentionality object) and recognizes that each activity is an activity to realize something. It is a process of realizing the effect of the so-called constitution, i.e. when the phenomenon appears to consciousness [27].

With respect to the paradigm, Thomas S. Kuhn insists that it means the whole beliefs, values, and techniques shared by members of a particular community. In this context, it could be devoted to the scientific community. Paradigm is also as a form of reconstruction modes of thought and modes of inquiry, which then produces modes of knowing something [28]. Also, it is commonly understood as the basis for selecting the issue in order to solve problems in research. Of course, it can also be interpreted, in relation to human life in general, as a perspective to understand the reality of life.

Consciousness is a process of understanding reality, regardless of the model or the cluster of thought/paradigm. This means that the cluster contained paradigm set forth by the essential structure of consciousness, since they are established simultaneously. If education is understood as a process of interaction between man and his world [29], then it is clearly based on the capacity of its consciousness and worldview/paradigm. In turn, education will change people's quality at looking at mythical, ideological, and scientific phenomena after going through the process of education.

\section{The Muslim community of Yogyakarta and Their Type Awarenesses}

The Muslim community of Yogyakarta is those who are permanent residents of Yogyakarta. In 2010, their number reached 374,816 or $79.86 \%$ of the total population of 388,088 people [30]. The form of educational paradigm in the context of Muslim awareness of Yogyakarta is only associated with the political and legal behavior, while in the political field, only the PDIP, Golkar, Partai Demokrat, PKS, PAN, PPP, and Gerindra factions in the Yogyakarta Regional Parliament. In the legal field, the law enforcement agencies such as police, judges and prosecutors will be observed.

\section{World View of Muslim Community of Yogyakarta \\ 3.1. Ontology}

Ontologically, the Muslim community of Yogyakarta understand the realities as they appear. The political behavior that always puts money politics and political ruses is the world view (basic ontology) of Muslim community of Yogyakarta, which was monotheistic, simple, short-term, instantaneous, reflecting mythical paradigm. They dismissed dialogue, felt self-righteous, worshipped individual, were fanatical, and extrovert. They maintained normative cultural behaviors and the approach was structural, instead of egalitarian and human. Next, the main characteristic of 'ilmiyyah was pluralistic ontological base, showing open, creative behaviors without hegemony and domination. Facts in this stage become social facts and the approach is cultural [31]. This view is reflected in behaviors that uphold the values of humanity/humanism, where truth can reveal as it should.

The scientific awareness in the Yogyakarta Muslim is represented by voters who rejected money politics in the regional election, nomination of Distric Parliament, as well as the nomination of village heads. All is represented by candidates and voters who did not want to dirty politics [32]. However, the mythical, ideological, and scientific awareness is evident both in political and legal behaviors. Mythical and ideological paradigms could be seen from the bad dealings conducted by police officers, judges and prosecutors, and the community.

\subsection{Epistemology}

The concrete illustration of the epistemology of Muslim community of Yogyakarta is in the case of political zealots among the elite and the sympathizers; because I am NU then I have to play politics to NU and PKB or through PPP [33], or because I am Muhammadiyah I must exercise my politics through PAN. The conclusion (structure, methods, and validity of knowledge of PKB, PPP and PAN-owned), is based on an analogy and built on deductive reasoning; NU-Gus Dur-Partai Kebangkitan Bangsa, Muhammadiyah-Amin Rais-Partai Amanat Nasional.

On the other hand, those with scientific ('ilmiyyah) paradigm based their conclusion on the plural, creative, open and dialogical flow of thoughts, i.e. inductive reasoning. Politics is seen as a means, rather than the end to achieve and realize the truth. For them, exercising their politics through NU or Muhammadiyah regardless their religious orientation was common. Political action was based on data driven inductive reasoning, instead of on subjective, analogical and deductive reasoning.

The mythical and ideological paradigm in the Muslim community was reflected in their collusive legal behaviors between police-prosecutor-judge in the case of speeding tickets. Truth is subjective. In contrast, those 
who believe in scientific paradigm distance themselves from collusion, corruption and subjective interests. They obey the law and any violation should be resolved through proper legal channels.

\subsection{Axiology}

For Muslim communities of Yogyakarta, morally upstanding people are those who realize the value of selfless behavior-hard working-maintaining peace on earth; sepi ing pamrih, rame ing gawe, hamemayu hayuning bawana [34], and it's all in the form of dharma bhakti/devotion. Its realization, however, largely depends on the levels of awareness, be they mythical, ideological, and scientific. Those with mythical and ideological awareness tend to have subjective political and legal, in accordance with the basic ontology and epistemology. Those with scientific paradigm tend to have objective political and legal ethics.

\section{Type of Yogyakarta Muslim Awareness}

4.1. Jahiliyyah

Derived from the verb (tajâhala al-Amr / تجا هل الامر), the word jahiliyyah means "to act stupidly, lack of knowledge, or ignorance" [35]. It is asserted that ignorance and stupidity is an awareness/paradigm. Deliberate intention is based on fanatism, taste and tradition. This awareness has primitive, patrimonial, simple/quick, not creative, imitative, non-scientific, as well as closed characteristics.

\subsection{Diniyyah}

The word diniyyah [36], is derived from the name القضاء \الدين which means "decision". It also means \ ملة and الديانة obedience, compliance, customs, habits, religion, and belief. In the al-Qur-an it is called الدين الطاعة [37], also referred to as a form of diversity. According C.Y. Glock and R. Starck [38], one's diversity can be observed from his faith, religious knowledge, religious practice, religious experience, and social impacts. Those dimensions are the perfect unity of consciousness, when the condition, capacity and function merge in a balanced way. The emphasis on the importance of faith, charity and religious experience, without knowledge and the impact of social value will create imbalance.

It was found that people tend to respond to any non-religious issues from religious standpoints. Religion is used as the sole approach to manage life and overcome problems, either personal, political or legal. This means that they are true to the Qur'an and Sunnah; QS An-Nisa' 14: 59. On the other hand they reject every political and legal action that deviates from the two basic laws. Those who responded to the issue with extreme assertiveness; by calling governments and other believers as infidels (kafir) and by waging war against those professing different faiths were FPI, MMI, HTI and Lasykar Jihad [39]. Those who were moderate distance themselves from the weak-willed people, by strengthening their own faith from within through Jamaat Tablig, several groups tareqat and Ihwan al-Muslim/Muslim Brotherhood.

\section{3. 'Ilmiyyah}

The word is derived from the name علمية meaning "based on science." [40]. According to Kuntowijoyo [41], scientific awareness characterized by an attitude of openness/open ended. It is based on the determination to reach out and strengthen objectivity for each view. The main value, besides openness, is being realistic in making sense of things. Due to domination of modern paradigm, such as renaissance characterized by its positivistic and pragmatic advancement in science and technology, reality is reduced to its empirical, naturalistic sense, in which objectivity, from the 'ilmiyyah point of view, can be measured, observed, and verified in terms of its benefits for man.

The Muslim community in Yogyakarta who have scientific awareness reject money politics during pilkada / regional election. They vote for candidates whose vision and mission can be measured and accounted for. Therefore, these people's votes will not be bought (zero money politics). In addition, they will punish votebuyers by not voting the party in the next election [42].

\subsection{Hanifiyyah}

The word الحنف or الحنتقيم /الاستقامة (الحنيف), means "being straight/candid", also called الحنفية في الاسلام meaning "cling to Islam" [43]. QS al-Nahl/16: 120 and 123 said hanif is associated with Prophet Ibrahim, whose mind was always straight. Thus, reality might not exist without attempts to balance spiritual powers. Hanifiyyah is described in the the implementation. Qur'an S. Al-An'am verse 74-79 describes Prophet Ibrahim's ability serve God obediently. In other words, his life was always based on tauhid (that God just One).

His personality can be understood from his statement in verses 74-79 of Q. S. al-An'am. First, empirical cognitive made him consciousness phenomenologically, in Husserl's terms [44], to analyze and conclude that objective truth exists and can be achieved. Doubt is replaced with certainty. Second, the next stage is intuitively [45] interpreted as wisdom, judgment, or inspiration. Ibrahim conducted an in-depth understanding of the process and concluded that something exists beyond the senses and rationality. 
People with hanifiyyah paradigm can be found among the Muslim community in Yogyakarta. There are two people belonging to this paradigm. First, Sri Sultan Hamengku Buwono IX (The King of Ngayogyokarto Hadiningrat Kingdom). He had a simple, disciplined, humble, populist, thoughtful, and fair persona. His remarkable personality was standing out in two events: 1 . When police gave him a ticket for violating traffic signs, and 2. When he helped a merchant women (bakul. Java) at the Kranggan market.

One day the Sultan was pulled over by a policeman for violating traffic signs. He was asked to show his driver's license. Being the Sultan, he could have scolded or suspended the police officer. Instead, the police officer was promoted to Pekalongan or Semarang to Yogyakarta for doing his duty well. This shows how wise (Wicaksana, Java); honest, fair, simple, and steadfast the Sultan was and it clearly shows how he was devoted to practicing Islam in his daily life [46]. On another ocassion, when the Sultan was driving, a peddler flagged him and asked him to give her a ride to Kranggan market in Yogyakarta. Obviously, the peddler thought he was one of the drivers who drove traders to the market. The Sultan obediently granted the peddler's wish; loaded her stuff and drove the women to the market safely. When he refused the payment, the peddler scolded him for being so greedy. When she found out who he was, she was shocked for disrespecting the king and fainted [47].

The second person was KH. AR Fakhruddin, a wise, honest, fair, simple man who understood Islam and practiced the Prophet's teachings in his daily life. One day when he went to get a driver's license. He did not want to bribe the police officer or took a shortcut. So, even though he was already a competent motorcycle rider, still he took a written and practice tests. Nobody recognized him with his full-face helmet. He deliberately did that to avoid getting easy pass because he was KH. AR Fahrudin, the Chairman of the PP. Muhammadiyah). Had the police officer known him, the driver's license would have been delivered to his house [48].

\section{Education Paradigm of Muslim Community of Yogyakarta in the Context of Types of Awareness} The Muslim community's education paradigm based on their types consciousness are described as follows.

5.1. Jahiliyyah

\subsubsection{Ontological Basic}

Reality is seen as it is, while at the same time the same reality is seen as something contradictory. This happens deliberately. The subject dominates the object in distorting facts. Ontologically, they should belong to dualism, but in practice they despise reality or afterlife, making the empirical or material world as their priority.

For progressivists, reality is not merely a concept. Reality is always changing, not stagnant. Therefore, reality may not be understood in an instant, short, and simple, but in the process of change itself. In this case, progressivism views are dialogical, plural, spiral, and indeterminate.

\subsubsection{Epistemological Basic}

Sources of human knowledge can be from outside himself (object/empirical) and from within (subjective/rational/intuitive or beliefs). The validity of knowledge is certainly empirical, rational and intuitive. In contrast, Progressivism views that knowledge evolved in its dialogical, indeterminate, plural, and spiral.

\subsubsection{Axiological Basic}

If what is valuable contains the goodness or morality, the value of thing for people with jahiliyyah paradigm is what is instantaneous and distorted from reality.

\subsubsection{The Concept of Human}

The goal in life is to be an individual with jahiliyyah paradigm, namely a two-faced people with double characters. On the one hand, they understand, but on the other they deliberately act stupid or ignorant. For example, he is a Muslim, but he does not implement Islamic teachings contained in the al-Qur-an and alSunnah.

\subsubsection{Theory and Method of Learning}

Learning is a normative confirmation absolutism on experience for the community who has jahiliyyah paradigm. Experience is measured with a norm that is considered subjectively true, merely complementary instead of fundamental. Subject is crucial in gaining knowledge. However, since the subject tends to put experience in the spotlight and this is where reality is distorted. Their stagnant way of thinking affects their imitative method of learning, making them unable to develop themselves critically. The learning method tends to be contradictory, instructional and indoctrinating. The process of material or cultural transfer from one generation to another is monotonous.

\subsubsection{Curriculum}

Since their epistemology tends to be subjectivistic, the designed curriculum is a model subject matter curriculum. Unlike in progressivism, which pays attention to the individual needs by keepeing abreast with the real condition, the jahiliyyah intends to steer the subject the subjective norms. 


\subsection{Diniyyah}

\subsubsection{Ontological Basis}

The diniyyah paradigm recognizes the world and the Hereafter and differentiate them hierarchically; afterlife is more important than the physical world. Ontologically, it includes the view of dualism, which means that reality is in a state of material/lower world while the spiritual world is considered higher. As a result, people tend to focus on the higher one, without abandoning the world altogether. Such ontological view is guided by the source of truth (al-Qur'an) from Allah, translated to the Sunnah by the Prophet. God the creator is hierarchically higher than human beings, as creation and God's agents.

\subsubsection{Epistemological Basis}

The source of human knowledge is the object. If reality is material, then the means of acquiring knowledge is sensory, while the spiritual experience is gained through intuition/ affection. Thus, rational truth is rejected. However, the rational mind still works to explain the name, position, quantity, functions, and relations, the existence empirically, and the spiritual (God, angels, genie, and the afterlife) is acquired through the process of acquisition by intuition, or revelation of God through His Messenger. The validity of each knowledge is based on the quality of the object and the means of acquiring knowledge; empirical-sensory and sensory/logical, and spiritual-intuition. Since human is ontologically God's representative on earth, and all his work must always be in accordance with His will, all knowledge is defined by God's will (qudrah Ilahiyyah).

\subsubsection{Axiological Basis}

Referring to the ontological and epistemological basis, then the goodness and decency must be in accordance with Islamic law. This view is reflected in their legal and political behavior, on their call to the government to implement Islamic law, not in a radical way because the government is recognized as uli al-amri, which gives non-Muslim citizens the right to carry their religion. Therefore, they are two-faced.

\subsubsection{The Concept of Human}

These are humans formed by the ontological, epistemological, and axiological basis of the diniyyah paradigm; the man who clings to the teachings of Islam. Religion is used as the sole approach to managing life and overcoming problems and other approaches are rejected.

\subsubsection{Theory and Method of Learning}

Learning is the confirmation of experience. Since the subject prefers total submission to God, he is dominated by those in higher power than himself. Thus, acquiring truth or knowledge is through intuition and due to their submissive attitude, learning tends to be imitative (preserve the normative and aligning historicity to norms), making them unable to think critically. The instructional methods are linear, imitative and indoctrinating.

\subsubsection{Curriculum}

Since the educational format is beased on subjectivistic epistomolgy, the curriculum is designed as a subject-matter curriculum. The curriculum is designed to meet the need of the individual in accordance to the norms. If needs to revise the curriculum arise, principal aspects such as objectives, content/materials, methods, and evaluation are not developed. Instead, the inessential outward aspects such as educational media, building, desks, administrative supplies, are developed.

\section{3. 'Ilmiyyah}

\subsubsection{Ontological Basis}

The reality is empirical/concrete as well as quantitative. Under various conditions, reality is different, dynamic, and constantly changing. This ontological basis manifests in the political behavior in the form of the principles in the general election, namely direct, general, free, confidential in Yogyakarta. This can guarantee the achievements of targeted election results. In addition, the politicians refuse to apply money politics during general elections. Dirty politicians are punished by the public who will not be selected again [49].

\subsubsection{Epistemological Basis}

Those who have ilmiyyah paradigm see that reality exists outside himself (objects), which becomes the source of knowledge. The process of acquiring knowledge is done through empirical perception. Their scientific attitude requires him to perform scientific tests (observation, verification, and measurement). Thus, the knowledge is more reliable and valid. In politics, this scientific approach is reflected in the accurate estimation of how many voters for specific mayor candidates based on the regional divisions (neighborhood, village and subdistrict levels) and the voters' professions. However, it is worth noting that such calculations only apply to 
the calculation of electoral facilities and administration. They do not apply to predict voters' political attidude. The results are only based on general estimation, and therefore are not 100\% accurate. The data from Yogyakarta Election Committee shows this generalization and prediction [50]. In legal field, it is commonly known that judges should not be more than 58 years old. However, Sahlan Said said that he had a 60 -year-old friend nearing his retirement who was appointed as a high court judge [51]. It shows that 'ilmiyyah paradigm cannot be applied in social sciences and humanities because people's attitudes and behavior cannot remain constant, but always changing.

\subsubsection{Axiological Basis}

The measure of what is good and of high moral for the Muslim community in Yogyakarta who has 'ilmiyyah paradigm is based on an objective behavior. It means that good manners and decency are not imposed by others (imperative categories/scientific). Behavior is linear (positivistic) and must be completed. The significance/meaning of reality (particularly socio-humanities) is not even addressed. There is a gap in their axiological/ethical basis.

\subsubsection{The Concept of Human}

The goal is to achieve human character who is 'ilmiyyah, i.e. seeing life as it is. As life is ever-changing and dynamic, ilmiyyah people are those who can follow the rhythm of life and make changes accordingly. These human beings have creativity, innovation, and progress, but their behaviors are very mechanical and systemic. Problem solving in politics and law is done in a linear plot; measurable, observable, verified beginning and end. In politics, everything is seen as black and white, cause and effect, data-driven. In legal field, this step ensure justice will be done, because the rule of law is definite and the consequence is certain.

A legal settlement follows such procedures in deciding cases (black and white), but the material (humanity) may not be touched. For example, two thieves are brought to the court. They would likely receive the same punishment, so the formal side of the law is met. However, the material (humanity) has not been met. Under close examination, these two thieves have different conditions. One thief may steal for a living, and the other steals out of necessity. Therefore, the law treatment should not be exactly the same for both.

\subsubsection{Theory and Method of Learning}

Theory and methods of learning among the 'ilmiyyah paradigm [52] are in the form of Learning by Doing. It aims to develop the potential of educated intelligence to solve problems. If reality is understood as empirical, the acquisition of knowledge (learning) implies that learners must experience it. Therefore, what he learns is the result of his own understanding, intead of someone else's (teacher's experience). It is expected that the learner's potential and capacity develop naturally. Learners should be treated as individuals, not as a group and therefore must be liberated to choose objects of learning and the media to suit their individual needs.

\subsubsection{Curriculum}

The curriculum should be designed to suit the needs of the learners to develop their potential and capacity. The child-centered curriculum must be rich and varied and promote their development. On the one hand, the learning materials are too packed; on the other hand, the learners will gain various competence to deal with life problems.

\subsection{Hanifiyyah}

\subsubsection{Ontological Basis}

The ontological basis of reality is real and possible. The abstract includes what is near (spiritual) and far (God, angels, genie, heaven, hell, and the afterlife). To understand this, humans have the means, i.e., the senses, reason, and intuition. Based on the tauhid (One God), humans with hanifiyyah view that reality is associated with God himself, manifests beyond the capacity of human knowledge. God cannot be explained without referring to the Qur'an, which does not clearly explain the exact substance of God either. Knowledge about God is God's own right. Human capacity cannot change reality of the universe, i.e. changing the course of Sun's orbit or changing barren desert into a fertile agricultural land. That is the ontological basis of hanifiyyah consciousness. It means that realities are real which humans can reach through sense, reason, and intuition.

\subsubsection{Epistemological Basis}

Human knowledge includes sensory, rational, and intuitive elements. One is not higher than the other. Human beings use the means to gain the knowledge, i.e. sensory for empirical knowledge and rational means to clarify the state of the object. For example, to understand the star in the sky, people must not rely only on sensory data because they can be wrong. In reality, stars are much bigger than what human eyes can see. Things are smaller when seen from the distance. Human eyes have limited capabilities. Knowledge is also achieved 
rationally and confirmed by sensory experience. Whe trying to understand phenomena which cannot be fathomed with their sensory elements, human beings must use intuition which is confirmed by logic. God, angels, heaven, hell and genie in the hanifiyyah paradigm are believed without having to be verified empirically. For things that they cannot touch or explain through sensory, human beings rely on their faith to believe it.

\subsubsection{Axiological Basis}

Kindness and decency for people with hanifiyyah paradigm is empirical-rational-intuitive. People should have empirical, rational and intuitive behaviors to achieve the objective/essential truth. Goodness and decency is objective/realistic the fact is empirical or rationally justified, and valid. For example, rationally and legally, every citizen must have a motorcycle driver's license (SIM C), without exception through written and practice tests. Therefore, any behavior reflecting otherwise is considered immoral or sinful. The hanifiyyah paradigm requires behaviors which do not condone bribing, taking and giving gratification, corruption and so on.

\subsubsection{The Concept of Human}

Humans with hanifiyyah paradigm is the standard. This kind of people are able to be self-conscious based on their ontology, epistemology and axiology. They reflect creative, dynamic, progressive, innovative, objective and rational personality. According to Emotional Quality Management theory [53] states that through discipline, people of this kind can manage their emotions (knowing themselves in perspective of One-God and use them well). Being the agents of God, they must do God's will. God, in His perfect asma' al-husna/good names, they must try to be perfect. They are characterized by their natural rational thinking within the open scope of possibility. In short, human the true human selfhood is in its natural state; which affects and is affected by the realities of life.

\subsubsection{Theory and Methods of Learning}

Learning is a process of becoming (To Be), and truth is the character (The good character of Being Human in Religious Conciousness). Meanwhile, truth is objective. For this reason this theory is called learning Objective Theory (Theory of Being Objective). Process is understood as the normative and historical development and or expansion in a dynamic atmosphere. It means that tawhid ( being the standard norms, the Qur'an and the Sunnah of the Prophet) should be realized in the historical area/living in reconstructive dynamics (always up to date). The reasoning is not deductive or inductive, but abductive [54], which is characterized by the spirit of discovery and inquiry. This affects the relationship between the subjects of education marked with dialogue, critical and productive discussion, not instruction.

\subsubsection{Curriculum}

The content of the curriculum can be achieved if the objectives are suited to the objective needs. First, curriculum must be able to develop human potential in terms of cognitive, affective, and psychomotor aspects [55]. The materials should develop sensory, rational, and intuitive competencies. Second, the curriculum is always up-to-date, and always becomes the truth in itself. The natural law establishes in $Q S$ al-Thalaq verse 7: that God does not impose the burden to someone more than what God has given him [56]. Therefore, the curriculum must be nuanced with real, rational, and religious consciousness.

\section{Hanifiyyah Education Paradigm And Its Role For Indonesian Character Building}

Character building has not been achieved comprehensively and maximally. Local and international seminars have addressed the problems caused by Indonesian negative characters such as corruption, violence, sexual crimes, vandalism, brawls, consumptive economy, unproductive political situation, and so on. Various alternative solutions such as regulations, laws, increased law enforcement are proposed [57]. Those negative characters are proofs of the researcher's point that the Muslim community in Yogyakarta still belong to jahiliyyah and diniyyah paradigms. These paradigms can be seen from their stupid behaviors and strong baseless fanatism. Those with 'ilmiyyah paradigm are dominated by positivistism, making their approach to life-style linear, mechanics, and black-and-white. Life must be managed multidimensionally in order to be objective and human. To achieve this goal, the establishment of the nation's character should be based on the hanifiyyah paradigm of education, because it can lead people to their true condition/objective. This includes several key elements of educational program and its implementation, i.e. the basis (ontology, epistemology, and axiology), goals, theories and methods of learning, and curriculum.

The ontological, epistemological, and axiological basis of hanifiyyah is a philosophy of life that includes the value of monotheism/faith, syari'ah, and worship or in the form of monotheism, science, and charity. These values were the basis to implement education. If a man who has hanifiyyah character is creative, progressive, objective and rational, this is the manifestation of his philosophy of life, achieved through applying 
the theories and methods of objective learning. Conceptually, the theory contains steps to deliver Muslim community to their awareness of "being" (able to identify, sort and select the means, manner and object of study accurately) in order to be straight/hanif; to lead, not be led, to be conscious and not manipulated. This can be achieved when the curriculum is, first, able to develop the potential of human beings; based on Bloom's theory [58], namely cognitive, affective, and psychomotor. Second, the curriculum should be in line with the changing times, and to remember the truth itself is in process. The natural law establishes in QS al-Thalaq verse 7: لايكلف

اله نفسا الا ما اتها Therefore, the curriculum must be nuanced with real, rational, and religious consciousness.

\section{Conclusion}

Educational paradigm and human consciousness have a simultaneous relationship. Theoretical findings of experts only focused on the discussion of the type of human consciousness without associating it with the paradigm of education. They only proposed three kinds of paradigms. However, through a careful research on the Muslim community of Yogyakarta, the researcher identified four types of awareness, namely Jahiliyyah, diniyyah, 'Ilmiyyah, and Hanifiyyah. Jahiliyyah (act stupid), reflects the attitude of patrimonial humans, who take short cuts, are not creative, imitative, not scientific, and narrow-minded. Diniyyah (normatively and exclusively religious spirit), a view which splits in dualism; the world versus hereafter, the religious versus unreligious, and material versus unmaterial. Religious values are adhered to run their life. 'Ilmiyyah (academic), the positivistic and pragmatic human attitude nuanced, reducing reality to empirical, naturalistic, and benefit values. Hanifiyyah (self-conscious and straight), a state of mind that is always conditioned and straight, which means that it will not exist without an effort to stabilize and balance the spiritual forces in the implementation.

Based on the data, the researcher found an association between the type of awareness simultaneously with four education paradigms proposed by the researcher, namely jahiliyyah, diniyyah, 'ilmiyyah, and hanifiyyah. Jahiliyyah educational paradigm is characterized by the emphasis of its educational theory on normative absolutism, in which experience is measured with perceived norms (subjective). Diniyyah educational paradigm, like jahiliyyah, also imposes normative absolutism on experience, in which normative adherence to the Qur'an must be followed strictly. 'ilmiyyah educational paradigm emphasizes on Learning by Doing. Hanifiyyah educational paradigm which adopts the Objective Theory posits that in the process of becoming, or the development and normative and historical expansion last dynamically. It means that tawhid ( being the standard norms, the Qur'an and the Sunnah of the Prophet) should be realized in the historical area/living in reconstructive dynamics (always up to date). The contribution of this research on the development of the concept of Islamic education is the discovery of theories of Islamic education in the form of Objective Theory. It is essential for the formation of the character of the Muslim community in Yogyakarta (Indonesia) at present and in the future.

References

[1]. Harriet Martineau, (Translater \& Condenser). The Positive Philosophy of Auguste Comte , With an Introduction by Frederic Harrison, In three Volume, (London, Batoche Books, Kitchner, 2000) 27-28. And, Koento Wibisono, Arti Perkembangan Menurut Filsafat Positivisme Auguste Comte, (Yogyakarta, Gadjah Mada University Press, 1983) 11-21.

[2]. Omi Intan Naomi, "Pengantar: Mendidik si Alim, Pembangkang, Pemberontak", In Menggugat Pendidikan Fundamentalis, Konservatif, Liberal, Anarkis, (Ed.) \& Translated by Omi Intan Naomi, (Yogyakarta, Pustaka Pelajar, 1998) pp. xxxv-xxxvi.

[3]. C.A Van Peursen, Strategi Kebudayaan, terj. Dick Hartoko (Yogyakarta, Kanisius, 1974) 21.

[4]. C.A Van Peursen, Strategi Kebudayaan, terj. Dick Hartoko (Yogyakarta, Kanisius, 1974) 91.

[5]. C.A Van Peursen, Strategi Kebudayaan, terj. Dick Hartoko (Yogyakarta, Kanisius, 1974) 92-93.

[6]. Paulo Freire, Education for Critical Consciousness, The English-language edition for it was prepared in association with center for the Study of development and Social Change Cambridge USA, Massechusetts, 1973) 17.

[7]. Paulo Freire, Education for Critical Consciousness, The English-language edition for it was prepared in association with center for the Study of development and Social Change Cambridge USA, Massechusetts, 1973) 18.

[8]. Paulo Freire, Education for Critical Consciousness, The English-language edition for it was prepared in association with center for the Study of development and Social Change Cambridge USA, Massechusetts, 1973) 18-19.

[9]. Malcom Knowles, A Trainers Guide to Andragogy, Revised Edition (Washington D.C, US Departement of Health, Education and Welfare, 1973) n.p.

[10]. M. 'Abid al-Jabiry, Bunyah al-'Aql al-'Arabi: Dirasah Tahliliyyah Naqdiyyah li Nuḍ̂mi al-Ma'rifah fi al-Tsaqafah al-'Arabiyyah, (Beirut, Markaz Dirasah al-Wihdah al-'Arabiyyah, 1990) (Third ed.) 15-36.

[11]. M. 'Abid al-Jabiry, Problem Peradaban: Penelusuran Jejak Kebudayaan Arab Islam dan Timur, translated by Sunarwoto Dema, (Yogyakarta, Belukar, 2004) (first ed.) 83-84.

[12]. M. 'Abid al-Jabiry, Bunyah al-'Aql al-'Arabi: Dirasah Tahliliyyah Naqdiyyah li Nudûmi al-Ma'rifah fi al-Tsaqafah al-'Arabiyyah, (Beirut, Markaz Dirasah al-Wihdah al-‘Arabiyyah, 1990) (Third ed.) 251-256, 258-268.

[13]. M. 'Abid al-Jabiry, Problem Peradaban: Penelusuran Jejak Kebudayaan Arab Islam dan Timur, translated by Sunarwoto Dema, (Yogyakarta, Belukar, 2004) (first ed.) 163-164.

[14]. M. 'Abid al-Jabiry, Bunyah al-'Aql al-'Arabi: Dirasah Tahliliyyah Naqdiyyah li Nuḍ̂mi al-Ma'rifah fi al-Tsaqafah al-'Arabiyyah, (Beirut, Markaz Dirasah al-Wihdah al-'Arabiyyah, 1990) (Third ed.) 383-394.

[15]. M. 'Abid al-Jabiry, Problem Peradaban: Penelusuran Jejak Kebudayaan Arab Islam dan Timur, translated by Sunarwoto Dema, (Yogyakarta, Belukar, 2004) (first ed.) 106-107. 
[16]. M. 'Abid al-Jabiry, Problem Peradaban: Penelusuran Jejak Kebudayaan Arab Islam dan Timur, translated by Sunarwoto Dema, (Yogyakarta, Belukar, 2004) (first ed.) 106.

[17]. Kuntowijoyo, Muslim Tanpa Masjid: Esai-Esai Agama, Budaya, dan Politik Dalam Bingkai Strukturalisme Transendental, (Bandung, Mizan, 1998) 33-38.

[18]. Kuntowijoyo, Muslim Tanpa Masjid: Esai-Esai Agama, Budaya, dan Politik Dalam Bingkai Strukturalisme Transendental, (Bandung, Mizan, 1998) 74-76.

[19]. Kuntowijoyo, Muslim Tanpa Masjid: Esai-Esai Agama, Budaya, dan Politik Dalam Bingkai Strukturalisme Transendental, (Bandung, Mizan, 1998) 60-63.

[20]. Kuntowijoyo, Muslim Tanpa Masjid: Esai-Esai Agama, Budaya, dan Politik Dalam Bingkai Strukturalisme Transendental, (Bandung, Mizan, 1998) 74-81.

[21]. Kuntowijoyo, Muslim Tanpa Masjid: Esai-Esai Agama, Budaya, dan Politik Dalam Bingkai Strukturalisme Transendental, (Bandung, Mizan, 1998) 78-81.

[22]. Kaelan, Metode Penelitian Kualitatif Bidang Filsafat: Paradigma Bagi Pengembangan Penelitian Interdisipliner Bidang Filsafat, Budaya, Sosial, Semiotika, Sastra, Hukum Dan Seni, (Yogyakarta, Paradigma, 2005) 58.

[23]. Michael Quinn Patton, Qualitative Evaluation Methodes, (Beverly Hill, Sage Publication, 1980) 268.

[24]. Kaelan, Metode Penelitian Kualitatif Bidang Filsafat: Paradigma Bagi Pengembangan Penelitian Interdisipliner Bidang Filsafat, Budaya, Sosial, Semiotika, Sastra, Hukum Dan Seni, (Yogyakarta, Paradigma, 2005) 68-71.

[25]. Dermot Moran, Edmund Husserl: Founder of Phenomenology (Cambridge, Polity Press, 2008) 5-6.

[26]. Kaelan, Metode Penelitian Kualitatif Bidang Filsafat: Paradigma Bagi Pengembangan Penelitian Interdisipliner Bidang Filsafat, Budaya, Sosial, Semiotika, Sastra, Hukum Dan Seni, (Yogyakarta, Paradigma, 2005) 93-95

[27]. Dermot Moran, Edmund Husserl: Founder of Phenomenology (Cambridge, Polity Press, 2008) 5-6.

[28]. Thomas S. Kuhn, The Stucture of Scientific Revolutions (USA, The University of Chicago Press, 1970) 23, $25-27$.

[29]. Paulo Freire, Education for Critical Consciousness, The English-language edition for it was prepared in association with center for the Study of development and Social Change Cambridge USA, Massechusetts, 1973) 147.

[30]. http://bataviase.co.id (2010) 32.

[31]. Kuntowijoyo, Muslim Tanpa Masjid: Esai-Esai Agama, Budaya, dan Politik Dalam Bingkai Strukturalisme Transendental, (Bandung, Mizan, 1998) 60-63.

[32]. http://infokorupsi.com/id/korupsi. Downloded 28-10-2016.

[33]. Choirul Anam, Seandainya Aku Jadi Mathori,.Sembilan Pedoman Berpolitik Warga NU quoted from; (Surabaya, Bisma Satu Printing, 2002) n.p.

[34]. http://warta bumi.jogja.go.id

[35]. A.W Munawwir, Kamus Al-Munawwir: Arab-Indonesia Terlengkap, Edisi Lux (Yogyakarta, Pondok Pesantren Al-Munawwir, 1984) 236-237.

[36]. A.W Munawwir, Kamus Al-Munawwir: Arab-Indonesia Terlengkap, Edisi Lux (Yogyakarta, Pondok Pesantren Al-Munawwir, 1984) 472-473.

[37]. Yayasan Penyelenggara Penterjemah/Pentafsir Al-Qur'an, Al-Quräan dan Terjemahnya (Jakarta, Departemen Agama RI, 1978 ) 34.

[38]. [38] C.Y. Glock, dan R. Starck "American Piety: The Nature of Religious Commitment", In Roland Robertson, Sociology of Religion, translated by Paul Rosyadi (Jakarta, Aksara Persada, 1986) 288.

[39]. Kathleen Turner, http://id.wikipedia.org/wiki/Hizbut_Tahrir, 2006; pp. 2-7, and the http://id.wikipedia.en.wikipedia.org/wiki/FPI, and http://id.wikipedia.org/ wiki/MMI).

[40]. A.W Munawwir, Kamus Al-Munawwir: Arab-Indonesia Terlengkap, Edisi Lux (Yogyakarta, Pondok Pesantren Al-Munawwir, 1984) 1037.

[41]. Kuntowijoyo, Muslim Tanpa Masjid: Esai-Esai Agama, Budaya, dan Politik Dalam Bingkai Strukturalisme Transendental, (Bandung, Mizan, 1998) 60-63.

[42]. http://jontra-sihite.blogspot.com, election - the city - Yogyakarta - special. html

[43]. A.W Munawwir, Kamus Al-Munawwir: Arab-Indonesia Terlengkap, Edisi Lux (Yogyakarta, Pondok Pesantren Al-Munawwir, 1984) 328.

[44]. Dermot Moran, Edmund Husserl: Founder of Phenomenology (Cambridge, Polity Press, 2008) 5-8.

[45]. Bertens, K., Filsafat Barat Abad XX : Inggris - Jerman, (Jakarta, Gramedia, 1983) 263.

[46]. http://inmotivasi.blogspot.com

[47]. https://kissanak.wordpress.com

[48]. M. Sukriyanto M.Hum, http://www.Manadosoft.Com, and http://wakhadiwak.Blogspot.com).

[49]. http://jontra-sihite.blogspot.com, election-town-special-Yogyakarta.html

[50]. http://news.detik.com/read/

[51]. Sibodil, Tempo Interactive, March 13, 2008, n.p

[52]. Brameld, Theodore, Philosophies of Education in Cultural Perspective (New York, Holt, Rinehart \& Winston1955) 130.

[53]. Anthony Dio Martin, Emotional Quality Management: Refleksi, Revisi dan Revitalisasi Hidup Melalui Kekuatan Emosi, Jakarta, Arga, 2003) 82-85.

[54]. Sober, Eliot, Core Questions in Philosophy, Second Edition, (New Jersey, Prentice Hall, Englewood, 1995) 9-35.

[55]. S. Bloom, Benjamin, Ed., Taxonomi of Educational Objekctives : The Classification of Educational Goals, New York : David Mckay Company, 1974) 20-24.

[56]. Yayasan Penyelenggara Penterjemah/Pentafsir Al-Qur'an, Al-Quräan dan Terjemahnya (Jakarta, Departemen Agama RI, 1978) 946.

[57]. Badan Penelitian dan Pengembangan Pusat Kurikulum Kementerian Pendidikan Nasional, Bahan Pelatihan Penguatan Metodologi Pembelajaran Berdasar Nilai-Nilai Budaya Untuk Membentuk Daya Saing Dan Karakter Bangsa : Pengembangan Pendidikan Budaya Dan Karakter Bangsa, (Jakarta, Badan Penelitian dan Pengembangan Pusat Kurikulum Kementerian Pendidikan Nasional, 2010) 1 .

[58]. S. Bloom, Benjamin, Ed., Taxonomi of Educational Objekctives : The Classification of Educational Goals, New York : David Mckay Company, 1974) 20-24

[59]. Yayasan Penyelenggara Penterjemah/Pentafsir Al-Qur'an, Al-Quräan dan Terjemahnya (Jakarta, Departemen Agama RI, 1978) 946. 